\title{
Analyzing long-term empirical interactions between renewable energy generation, energy use, human capital, and economic performance in Pakistan
}

\author{
Nousheen Fatima', Yanbin $\mathrm{Li}^{1 *}$, Munir Ahmad² ${ }^{*}$, Gul Jabeen ${ }^{1}$ and Xiaoyu $\mathrm{Li}^{1}$
}

\begin{abstract}
Background: The current research attempts to systematically investigate the causal interactions between renewable energy generation, aggregated energy use, human capital, and economic performance in Pakistan both in a short-term and long-term test for the period of 1990-2016.

Methods: As a primary step, a unit root analysis was conducted employing, among others, an augmented Dickey-Fuller-generalized least squares (ADF-GLS) test. Based on the order of integration /(1), the Johansen and Juselius $(\mathrm{JJ})$ co-integration testing was employed to confirm a long-term causality analysis, which was followed by a vector error correction model (VECM) to calculate the short-run Granger causality analysis. Furthermore, the vector autoregressive (VAR)-based Cholesky test allowed the standard deviation impulse response functions to be generated to explain the responses of variables to arbitrary shocks in the data series under analysis.

Results: The empirical findings unearthed the bilateral causal connection between aggregated energy use and economic performance, renewable energy generation and economic performance, and human capital and economic performance. Thus, it confirmed the existence of feedback effects for aggregated energy use, renewable energy generation, and human capital in their relation to economic performance. Likewise, a unilateral positive causal connection was revealed running from renewable energy generation and human capital to aggregated energy use, and from human capital to renewable energy generation in both a long-term and short-term test. Additionally, the causal association running from aggregated energy use and renewable energy generation to economic performance was exposed in a long-term as well as short-term test, hence supporting the growth hypothesis.
\end{abstract}

Conclusions: The findings signified the importance of an enhanced generation of renewable energy along with the promotion of an aggregated energy use for the economic performance in Pakistan.

Keywords: Renewable energy generation, Aggregated energy use, Human capital, Economic performance, Pakistan

\section{Background}

Energy, ecology, and economy are strongly interrelated. However, due to the existing challenges associated with energy distribution and utilization, and in particular ecological issues, it is impossible for a society to achieve sustainable growth without employing eco-friendly energy methods. The challenges faced by the energy

\footnotetext{
* Correspondence: liyb@ncepu.edu.cn; munirahmad@zju.edu.cn

${ }^{1}$ School of Economics and Management, North China Electric Power

University, Beijing 102206, China

${ }^{2}$ School of Economics, Zhejiang University, Hangzhou 310027, China
}

sector are global warming, air contamination, harmful radiations, forest destruction, and ozone depletion. Additionally, the pressures on eco-friendly standards imposed by commercial development through energy usage as a channeling means are also the biggest challenges encountered by the energy sector. Since maximum efficiency procedures should be accompanied by a decrease of resource consumption and pollution emission, the production of energy is strongly connected with environmental influences. In addition to this, as all energy issues have some ecological effects, the limitations are more or

(c) The Author(s). 2019 Open Access This article is distributed under the terms of the Creative Commons Attribution 4.0 International License (http://creativecommons.org/licenses/by/4.0/), which permits unrestricted use, distribution, and reproduction in any medium, provided you give appropriate credit to the original author(s) and the source, provide a link to the Creative Commons license, and indicate if changes were made. 
less enforced by ecological effects on the sustainability and consequent adverse effects that could be overcome, at least to some extent, by promoting energy efficiency. Furthermore, the necessary modifications for improving renewable energy will help decrease ecological impacts, including health risks, and will promote sustainable development [1]. Hence, aggregated energy use, renewable energy generation, human capital, and economic performance are significantly interconnected, where the efficient administration of this nexus shall be profitable not only for the economic growth and human welfare of today but also as a prerequisite for the welfare of tomorrow.

The vitality of allied opportunities, challenges, and risks as well as the resulting consequences has recently drawn the attention of the global community. In particular, scientists were very successful in empirical studies focusing on the link between energy, environment, and economic nexus, with varied outcomes. Former research topics addressing the causal associations of energy, economic performance, and ecology might be categorized into the following seven groups: (i) renewable energy generation and economic performance [2], (ii) energy use and economic performance [3], (iii) renewable and non-renewable energy consumption along with economic performance [4], (iv) energy use and urban ecological sustainability [5], (v) human capital and economic performance [6], (vi) economic performance, energy usage, power excess, and growth of population [7], and (vii) energy, economic performance, and human capital at the same time [8]. These groups of researches, though in broad spectrum, were based on bivariate association without any distinction on the basis of nature of relationship as well as direction of linkages.

However, based on the nature and direction of the mutual effects among the variables of interest, the researches have been classified into four research lines. The first line of research analyzes the causal link between energy use and economic performance by stating that economic progress requires extensive energy use, and the efficient utilization of energy needs an improved economic performance. This causal connection has been extensively discussed in the literature, on the basis of "four energy hypotheses" [9]. Part of the first research line is also the "growth hypothesis," indicating that energy use has a substantial influence on economic performance and thus, strengthening the one-way causality association from energy use to economic performance. In continuation, the second line of research represents the "energy conservation hypothesis" indicating that a decrease of energy use has an adverse impact on GDP. The hypothesis declares a one-way causal link from development to energy use, whereas variations in economic performance cause variations in the use of energy. Thus, sudden changes in the supply of energy might either have less or no impact on development.

The third hypothesis refers to "feedback," which narrates a bilateral association among energy generation and use. Lastly, the fourth is "neutrality hypothesis" narrating the non-existence of any causal link between energy use and economic performance; thus, less energy use will have no influence on development. In contrast, human capital is an important factor to aggregate production, and is directly linked to economic growth [10]. Likewise, it is influential in the generation of renewable energy both via the absorption of new knowledge as well as the provision of labor [11]. The elements describing the connecting links between renewable energy generation, aggregated energy use, human capital, and economic performance are illustrated in Fig. 1.

Figure 2 draws a glance at the trends in energy use, renewable electricity output, and GDP per capita in Pakistan. Renewable electricity output has been observed to be $44 \%$ of the total electricity output in the year 1990 which declined and reached its minimum level of $25 \%$ in the year 2000. It was probably because of the situation that fossil fuel-based electricity output substantially increased the total electricity output due to heavy industrialization in China during 1990s. In this way, share of renewable electricity output in total electricity output declined during the said period. Afterward, it became stable and until the year 2016 was sustained at around $31 \%$. Energy use in 1990 was around $130 \mathrm{~kg}$ of oil equivalent that slowly but continuously declined and reached around $110 \mathrm{~kg}$ of oil equivalent by 2016 . The gross domestic product (GDP) per capita (constant US dollars 2010) was observed to be 741 US dollars in 1990 and gradually increased with the graduation of time and reached 1179 US dollars in 2016. In this way, generally, the real GDP per capita has shown a rising trend in Pakistan during the course of analysis.

\section{Literature review}

It is evident from the literature that energy [12-14], energy consumption $[15,16]$, and renewable energy have remained the major research interest for many academics. Similarly, the causal link between renewable energy and economic performance [17-19], and renewable energy and sustainable development [20-22] were studied in many articles. Biophysical, ecological, economic analysts and historians believe that economic performance is significantly influenced by the availability of energy inputs. However, while being very focused on the level of economic prosperity, the strength of this link varies dependent on various countries [23]. Thus, these authors determined the energy influence on the development of the economy from a geographical perspective by calculating an aggregate trans-log function of production, 


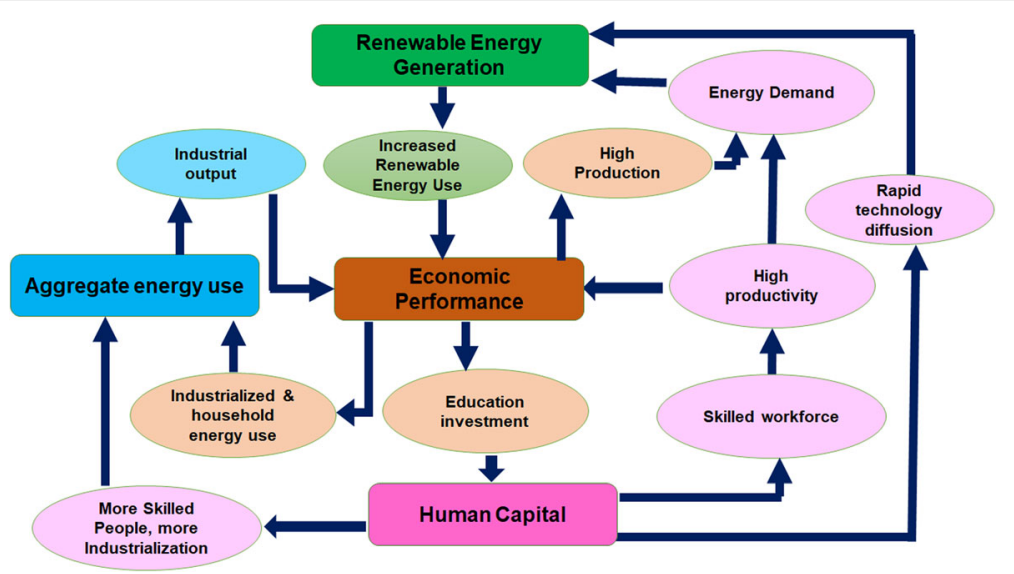

Fig. 1 Elements channeling the connections between renewable energy generation, aggregated energy use, human capital, and economic performance

with physical and human capital, and productive energy use as its factors, within the progress model. The data of 38 major countries from the year 1995 to 2007 were considered. The findings show the positively estimated productivity elasticities for energy consumption. All country panels, i.e., $15 \mathrm{EU}$ countries, have lower elasticities of about 0.12 while the BRIC countries have higher elasticities of about 0.37 . Weak substitutability relations between capital and energy determined for all groups were found, excluding the East EU and BRIC countries, demonstrating reverse relations [24]. W. Liu and Ayres [9, 25] studied the link of economic performance with energy, and Lean and Smyth [26] with energy usage while Ahmad and Zhao [27] analyzed the link of economic performance to energy investment.

Apergis and Payne [28] investigated economic progress and renewable energy use of 20 OECD countries for the period from 1985 to 2005 in a multivariate structure. The results show a long-term equilibrium link between renewable energy use, real gross fixed capital information, economic performance and human capital that indicates positive and strong associations. A bilateral causal link of economic performance and energy use, in both the long and short term, was found by means of the Granger causality analyses. Furthermore, Fang and Chang [8] analyzed the co-integration and causality link between energy use and economic performance for the period of 1970 to 2011 in 16 countries of the Asia Pacific. Adopting the latest augmented panel unit root and co-integration analyses allowed a cross-sectional dependence and a long-run co-integration association among the two stated variables to be determined. As shown by the Granger causality analysis of energy consumption in the region, the outcomes of statistical investigations were decisive for their economic development, whereas the association differs for distinct countries. The research conducted on energy use and supply from various sources in Pakistan recommended that the

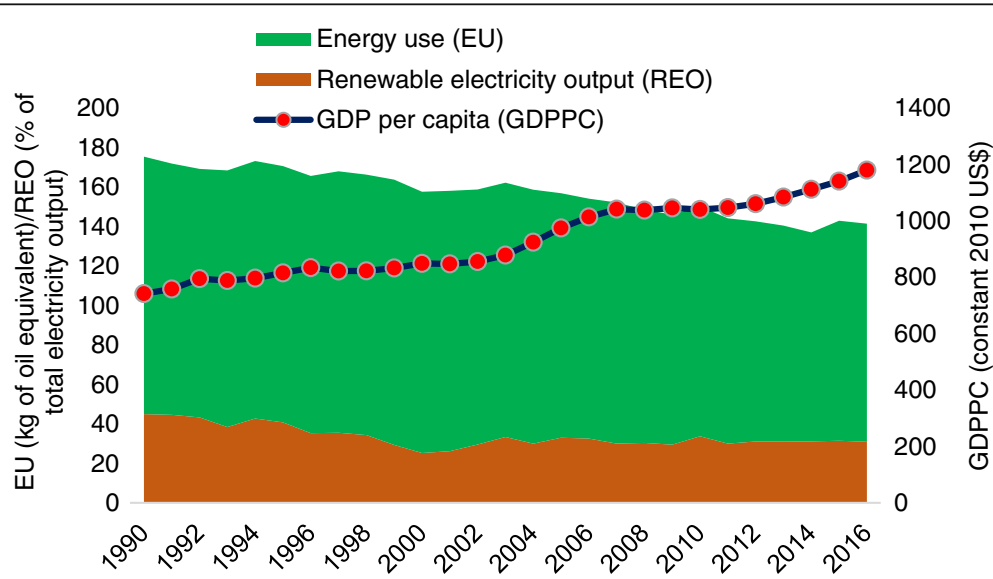

Fig. 2 A glance at trends in energy use, renewable electricity output, and GDP per capita in Pakistan 
government should promote the commercial use of aggregated energy and its supply from various sources to overcome the existing energy crises in the country [29].

Fang and Wolski [30] studied the causal link between aggregate and disaggregate energy use with GDPs for 1965 to 2014 in China. The nonlinear multivariate Granger causality analysis was used along with an expanded production function by incorporating both human as well as physical capital. The results declared the neutrality hypothesis for aggregate use of energy and coal, as well as natural gas, and hydroelectricity, whereas the unilateral causal link running from GDP to oil is proved from the results of the nonlinear approach, while a weak impact of human capital and energy was also noticed in the linear method. That means that the energy preservation strategies are practicable in China, and in addition, the strategies for human capital development, especially related to energy skills, might also be helpful for pollution reduction.

Stela [31] investigated the causal association between the aggregate and disaggregate levels of economic development and energy usage and determined them for the time period 1960 to 2006 in Greece with the aim to examine the time series data. The results proved the existence of a unilateral causal link between aggregated energy usage and real GDP at aggregate levels, while, at disaggregated levels, the findings demonstrated a causal bilateral connection of industrial/domestic energy usage and real GDP. Likewise, the author suggested that energy efficiency improvements should focus on the energy import dependence and demand side, which are significant for strategy implications on the structural strategies that affect energy usage in Greece. Altunbas and Kapusuzoglu [32] determined the relation of energy use to the GDP in the UK during the period between 1987 and 2007. Since the analysis results points to the non-existence of a co-integration connection among GDP and energy usage, it could be declared that there is no long-term association between the said variables; however, in the short term, a unilateral causality link between economic growth and energy use was detected.

The dynamic causal link among energy use, price, and GDP in the Kingdom of Saudi Arabia (KSA) was studied based on a demand-side approach, where Johansen's multivariate co-integration method was used by incorporating $\mathrm{CO}_{2}$ emissions as a control variable [33]. The results demonstrate the existence of a long-term unilateral causal link between energy price, energy usage, carbon emissions and GDP. In addition, a long-term unilateral causal link exists between energy use and the GDP on the one side, and carbon emissions, on the other. Likewise, a bilateral causal link between carbon emission and GDP and a long-term unilateral causal link from the price of energy to the GDP and to carbon emissions were detected. In the short term, however, a unilateral causal link exists between emissions and energy usage as well as emissions and economic progress from the price of energy to carbon emissions. Although the energy-led progress hypothesis is valid, the role of energy use in demonstrating the GDP is nominal. The most crucial factor in economic development determination is the price of energy. Therefore, the authors recommended that the strategies intended at decreasing energy usage and controlling carbon emissions might not decrease the development of the KSA significantly. Thus, to restrain carbon emissions and use of fossil fuels, investments in renewable sources such as wind and solar power are urgent requirements.

The research studies might be paneled as country or multi-country specific. The findings of prior literature research are not consistent and did not detect any indication to the existence of the above-mentioned relations between the respective variables [34]. Therefore, Ocal and Aslan [34] conducted country specific research of the causal relation between energy use and the GDP in the Turkish context. Outcomes of ARDL methods that supported the conservation hypothesis demonstrated a negative influence of renewable energy use on the GDP while the Toda Yamamoto's tests for causality confirmed a unilateral causal link between GDP and the use of renewable energy. The ARDL bounds test of cointegration and the vector error correction model (VECM) were employed to investigate the causal and long-term associations between renewable energy use, trade openness, economic development, and carbon emissions for the time span from 1971 to 2010. This research was carried out in the BRICS countries within the multivariate structure [35]. The results of the said study defended the feedback hypothesis by showing the existence of long-term equilibrium links between the mentioned variables, based on ARDL assessments that might demonstrate an impact of promoting renewable energy and the economic prosperity in the BRICS countries.

Human capital is one of the main factors of competitiveness and the GDP [36]. Nevertheless, the latest statistical data about unemployment in the EU expressed a few weak spots in this old perception. It is argued that human capital itself does not seem to ensure economic progress, it seems however to ensure the possibility to cope with economic challenges. Conversely, in countries, such as Spain or Cyprus, the level of human capital, measured as a proportion of people with tertiary education, is comparatively very high while unemployment has reached critical levels, and GDP growth rate has proved to be unstable or negative. Thus, from the study of Stoppok et al. [14], it becomes evident that human capital has to indicate the GDP, or if not, a higher level of joblessness might be created due to various impacts 
and instabilities in HR market. The study deals with local economic challenges and shows such dissimilar responses on the basis of structural variations and human capital capabilities. Ahmad and Khan [6] examined the association between human capital and economic performance. Kottaridi and Stengos [37] also determined the nonlinear impact of human capital on economic performance. Economic performance has a causal link with energy consumption, supporting the feedback hypothesis [38, 39], whereas Alaali et al. [40] analyzed the positive substantial influence of energy usage on economic progress, by suggesting to make energy usage efficient for ensuring a sustainable progress.

Rehman et al. [41] studied the causal association between carbon emissions and agricultural productivity in the perspective of Pakistan. The outcomes of the analyses demonstrated that the energy consumption of harvested land, and the obtainability of fertilizers and water, as well as the GDP are significantly related to each other and positively related to carbon emissions. Therefore, the researcher suggested that the state pay more attention to agricultural growth, which would be beneficial for the overall economic development of the country. Maamar and Salha [42] determined a long-run bilateral causality link between economic performance and renewable energy, and defended the feedback hypothesis. Similarly, Alaali et al. [40] found an association between economic performance and human capital by dividing human capital into health capital and education capital, where the education capital positively affected the economic development and where the health capital negatively affected it. Likewise, economic development is positively influenced by the innovative capability of human capital [43] and also by the capital stock and the use of biomass energy [44]. Thus, intellectual capital is significant for enterprises to attain sustainable growth and create their value [45].

Fang and Chang [8] presented an admirable literature review with regard to the energy, growth, and human capital nexus, which demonstrates that the awareness of these dynamic relationships provides a basis for the latest studies in the stated areas and helps to formulate effective economic strategies and promote eco-friendly energy policy goals. Furthermore, human capital has a larger nominal but marginal real effect on the national economy, and in particular, it could have a synergy influence on energy usage. Hence, economic experts might increase the allocation of resources to human capital investments, specifically, in the areas of competency development, to ensure the utilization of available advanced technologies and support the research of more energy efficient technologies.

In light of the surveys of the previous research studies, none of them dealt with an investigation of the long- term and short-term causal interactions among renewable energy generation, aggregated energy use, human capital, and economic performance in the perspective of Pakistan for the time series data comprised of 26 years, i.e., 1990-2016. Furthermore, previous research in this field did not consider the simultaneous relationships among those variables. These aspects provide a considerably huge gap to be bridged by the current study. Also, as the major part of the prior empirical studies analyzed the stated relationships on a piecemeal basis, thus the exploration of a four-way connection between the variables of interest distinguishes this research from the existing pool of other research.

The current study attempts to systematically analyze the empirical interactions between renewable energy generation, aggregated energy use, human capital, and economic performance for the time series data of Pakistan spanning from 1980 to 2016. In a detailed manner, the following contributions were deducted by this study. First, the order of integration of time series data was identified by employing a comprehensive unit root test considering, among others, the ADF-GLS unit root. Second, a long-term equilibrium association was established between renewable energy generation, aggregated energy use, human capital, and economic performance, which is the first ever attempt in the literature. Third, the simultaneous analyses of interactions among renewable energy generation, aggregated energy use, human capital, and economic performance in the perspective of Pakistan's economy can be seen as an initial empirical attempt taken by the current study.

The rest of the study is organized as follows: the "Literature review" section is based on data and methodology. The "Methods" section details the results and discussion of the study. Finally, the "Conclusions and implications" section concludes the work and provides some useful policy implications.

\section{Methods \\ Data and methodology \\ Data description}

The study intends to examine the long-term interaction between renewable energy generation, energy use, human capital, and economic performance in Pakistan. For this purpose, econometric tests were employed for the phase of 1990 to 2016. The data utilized are a time series based on an annual frequency compiled by using the World Development Indicators [46] and Penn World Tables (9.0) [47]. The data with regard to renewable energy generation, energy use, and gross domestic product (GDP) per capita were collected from the World Development Indicators while the data with regard to the human capital index were collected from the Penn World Tables. 
The description of the data utilized for estimations is as follows: The data on renewable electricity output (percentage of total electricity output) were taken to measure the renewable energy generation $\left(\mathrm{EG}_{\mathrm{R}}\right)$, whereas the energy use ( $\mathrm{kg}$ of oil equivalent) was taken to measure the aggregated energy use $\left(\mathrm{EU}_{\mathrm{A}}\right)$, the human capital index was used to measure human capital $\left(\mathrm{HC}_{\mathrm{IN}}\right)$, and the GDP per capita (constant US dollar) was used to measure the economic performance (EP). The trend in all the four variables is displayed in Fig. 3.

The functional form of the model to be estimated is as follows:

$$
\mathrm{EP}=f\left(\mathrm{EG}_{\mathrm{R}}, \quad \mathrm{EU}_{\mathrm{A}}, \quad \mathrm{HC}_{\mathrm{IN}}\right)
$$

\section{Unit root analysis}

First of all, the Augmented Dickey-Fuller (ADF) [48], the Phillips-Perron test (PP) [49], Kwiatkowski-PhillipsSchmidt-Shin (KPSS) test [50], and the Ng-Perron tests [51] of unit root analyses were conducted to determine whether the sequences were stationary. To support the outcomes of the stagnation analysis, all four tests were carried out at the same time. Likewise, the Schwarz Bayesian criterion (SBC), the Akaike information criterion (AIC), and the Hannan-Quinn Information criterion (HQC) were adopted to investigate the lag length, while conducting the unit root examinations. The outcomes of ADF and PP unit root examinations cited in Table 1 were the lag lengths calculated by AIC, SBC, and HQC.
The findings of the ADF and PP tests conducted on variables in the level form indicate that they are nonstationary, whereas the first difference form of the data series turned out to be stationary. In a similar way, the ADF-GLS test results supported the results of the ADF and PP tests results. Moreover, the application of KPSS with the trend came to the same results and supported the first difference as being without unit root. These statistical results are presented in Table 2 .

From Table 2, it is evident that the LM statistics for the level form variables are non-stationary as compared with those values that were found to be greater than the KPSS critical statistics at the significant level given as 5\% and, hence, as a result, it declared the series to have a unit root issue. Whereas, the outcomes found by the application of the same test to the variables in the firstorder difference form had regarded the series to be difference stationary. Thereby, the KPSS test findings endorse the results of the ADF and PP analyses.

Furthermore, the Ng-Perron unit root examination results (in Table 3) show a more reliable and effective outcome in the case of a small number of observations.

The null hypothesis of the MSB, MPT with the KPSS test results inclusive, reveals that the sequence is without unit root process, while the null hypotheses of the $\mathrm{MZ}_{\alpha}$ and $\mathrm{MZ}_{\mathrm{t}}$ analyses demonstrated that the sequence contains the unit root as found in the case of PP and ADF tests. The Ng-Perron test was executed by opting the Spectral OLS-Detrended Autoregressive Model, where the optimal lag order was identified and calculated based on the SBC, BIC, and HQ criterion. In order to keep the
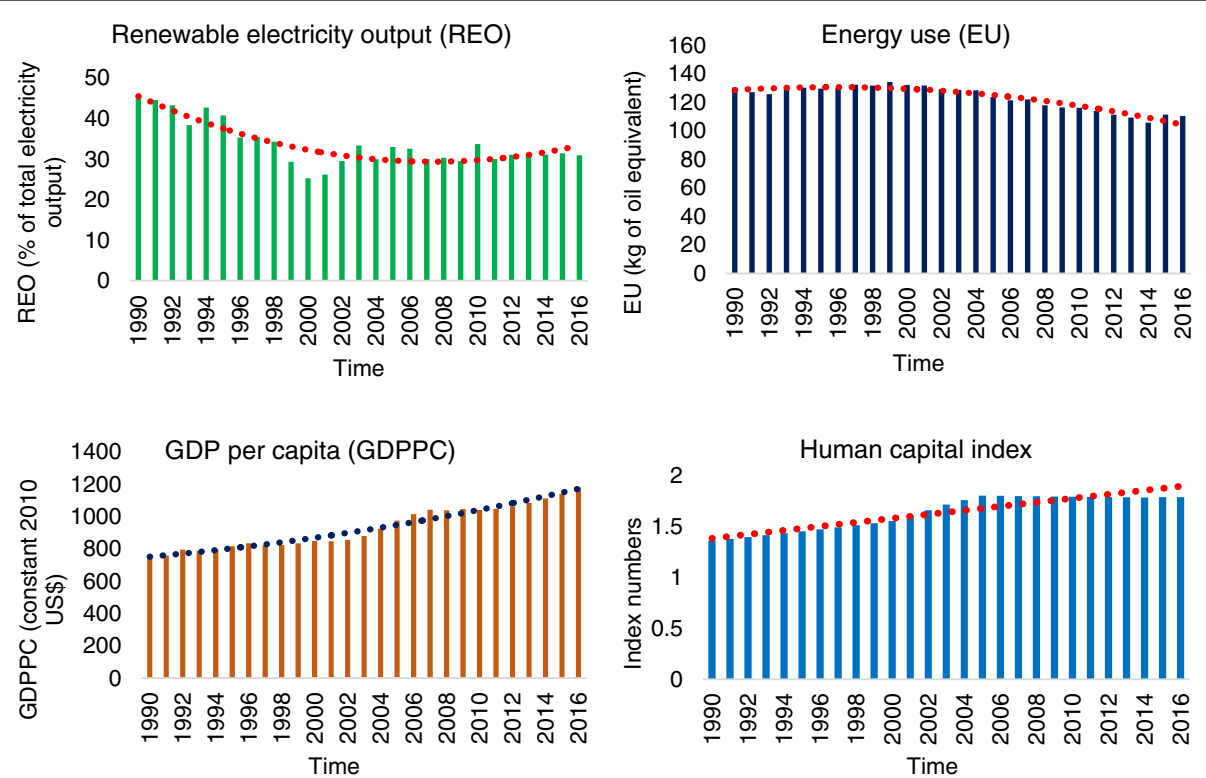

Fig. 3 The annual frequency-based time data series of energy use, renewable electricity output, human capital index, and GDP per capital in Pakistan 
Table 1 Results of ADF and PP analyses

\begin{tabular}{|c|c|c|c|c|c|c|c|c|}
\hline \multirow[t]{2}{*}{ Variables } & \multicolumn{2}{|c|}{ ADF test (statistics) } & \multicolumn{2}{|c|}{ PP test (statistics) } & \multirow[t]{2}{*}{ Tr./Fd. } & \multirow{2}{*}{$\begin{array}{l}\text { Unit } \\
\text { root }\end{array}$} & \multicolumn{2}{|l|}{ ADF-GLS } \\
\hline & & & & & & & $\tau$-statistics & ADF-GLS critical value (5\%) \\
\hline$E G_{R}$ & 2.734 & $P=0.433$ & 5.673 & $P=0.761$ & None & Yes & -2.713 & -2.996 \\
\hline$E U_{A}$ & -1.122 & $P=0.391$ & 0.015 & $P=0.153$ & Tr. + Fd. & Yes & -2.510 & -2.744 \\
\hline EP & -3.249 & $P=0.127$ & 3.805 & $P=0.368$ & $\mathrm{Fd}$ & Yes & -2.119 & -2.913 \\
\hline $\mathrm{HC}_{\mathrm{IN}_{\mathrm{N}}}$ & 5.347 & $P=0.849$ & 2.654 & $P=0.294$ & $\mathrm{Fd}$ & Yes & -2.885 & -3.185 \\
\hline$\Delta \mathrm{EG}_{\mathrm{R}}$ & -2.950 & $P=0.035$ & -3.930 & $P=0.050$ & None & No & -2.947 & -2.270 \\
\hline$\Delta \mathrm{EU}_{\mathrm{A}}$ & -2.509 & $P=0.005$ & -4.667 & $P=0.003$ & Tr. + Fd. & No & -3.125 & -3.002 \\
\hline$\Delta \mathrm{EP}$ & -6.623 & $P=0.018$ & -6.043 & $P=0.005$ & $\mathrm{Fd}$ & No & -2.983 & -2.316 \\
\hline$\Delta H C_{I N}$ & -5.665 & $P=0.036$ & -3.823 & $P=0.020$ & Tr. + Fd. & No & -2.722 & -2.601 \\
\hline
\end{tabular}

If $p$ value $>0.05$, then do not reject the null hypothesis of unit root

$E G_{R}$ renewable energy generation, $E U_{A}$ aggregated energy use, $E P$ economic performance, $H C_{I N}$ human capital index, $A D F$ augmented Dickey-Fuller test, $P P$ Phillips-Perron test, GLS generalized least square, $\Delta$ a first-order difference of variables, $T r$. trend, Fd. fixed, $\tau$ ADF-GLS test values, $P$ probability value

data as time-invariant, the lag length has to amount to one at the level form sequences. In addition, the firstorder difference of the series was $\mathrm{I}(0)$ for all the data series. For the structures displaying the constant and trend formation, the lag order in the level form of the sequence was found to be I(1). The first-order difference form for the sequence amounted to $I(0)$ for all the variables. In Table 3, series (1) is the first aware station since the statistical values of $M Z_{\alpha}$ and $M Z_{t}$, in the first difference form of the data series exceed the table values, and thus the value of MSB and MPT are less than the tabulated statistical values.

\section{Co-integration analysis}

Since all the data series incorporated in the structure are observed to be without a unit root at the first-difference, co-integration tests were employed along with a vector autoregressive (VAR) approach. In order to conduct the analysis, the vital criteria are the accuracy in the estimation of the VAR lag order, as ascertained by the AIC,

Table 2 Results of KPSS analysis

\begin{tabular}{lllll}
\hline Variables & LM (statistic) & Fd.-Tr. & KPSS critical value (5\%) & Unit root \\
\hline $\mathrm{EG}_{R}$ & 0.143 & Fd.-Tr. & 0.135 & Yes \\
$\mathrm{EU}_{\mathrm{A}}$ & 0.145 & Fd.-Tr. & 0.135 & Yes \\
$\mathrm{EP}$ & 0.239 & Fd.-Tr. & 0.135 & Yes \\
$\mathrm{HC}_{\mathrm{IN}}$ & 0.194 & Fd.-Tr. & 0.135 & Yes \\
$\Delta \mathrm{EG}_{R}$ & 0.067 & Fd.-Tr. & 0.135 & No \\
$\Delta \mathrm{EU}_{\mathrm{A}}$ & -0.003 & Fd.-Tr. & 0.135 & No \\
$\Delta E P$ & 0.119 & Fd.-Tr. & 0.135 & No \\
$\Delta H C_{\mathrm{IN}}$ & 0.085 & Fd.-Tr. & 0.135 & No \\
\hline
\end{tabular}

KPSS Kwiatkowski-Phillips-Schmidt-Shin test, $L M$ Lagrange multiplier, Tr. trend $F d$. fixed, $E G_{R}$ renewable energy generation, $E U_{A}$ aggregated energy use, $E P$ economic performance, $H C_{I N}$ human capital index
SC, HQ, and DIC. The VAR lag length was determined as recorded in Table 4.

As seen in Table 4, the information criterion values are provided with the evidence that a lag length of order 1 has been identified. The identification for a 1-year lag VAR structure was employed as a primary step. A white test to check the presence of homoscedastic series was carried out to confirm the absence of a variance issue of the error terms. As a next step, a Jarque-LM test was conducted for testing the autocorrelation issue. The statistical outcomes unveiled that there is no issue of variance for the given formations which also declares that the random errors follow the normal distribution that further confirms that there are no serial correlation issues observed. Thus, the identification test of a 1-year lag VAR structure confirms that the model was found to be consistent.

\section{Results and discussion \\ Co-integration-based long-term results}

In the current research, the Johansen and Juselius analysis [52] was performed for the co-integration test, which can be seen in Table 5 .

The empirical results in Table 5 show that the null hypothesis, claiming the existence of co-integration, was not accepted by the trace and highest eigenvalue test statistics, and one co-integration association is observed in each of the model specifications. It demonstrates the existence of a long-term connection between renewable energy generation $\left(E G_{R}\right)$, aggregated energy use $\left(E U_{A}\right)$, and economic performance (EP) in Pakistan. To further check the directionality of the said associations, normalized specifications are determined according to a $5 \%$ level of significance (Tables 6 and 7).

The normalized specification according to EO: 
Table 3 The results of the Ng-Perron unit root test

\begin{tabular}{|c|c|c|c|c|c|c|c|c|c|c|c|c|}
\hline \multirow[t]{2}{*}{ Variables } & \multicolumn{4}{|l|}{ Constant } & \multicolumn{4}{|c|}{ Constant +trend } & \multicolumn{4}{|c|}{ No (constant +trend) } \\
\hline & $\overline{M Z_{a}}$ & $M Z_{t}$ & MSB & MPT & $\overline{M Z_{a}}$ & $M Z_{t}$ & MSB & MPT & $\overline{M Z_{a}}$ & $M Z_{\mathrm{t}}$ & MSN & MPT \\
\hline$\overline{E G_{R}}(1)^{*}$ & -1.194 & -0.808 & 0.860 & 7.054 & -4.016 & -1.232 & 0.481 & 8.629 & -3.031 & -0.247 & 0.518 & 9.614 \\
\hline $\mathrm{EU}_{\mathrm{A}}(1)^{*}$ & -0.851 & -0.251 & 0.711 & 5.361 & -0.908 & -0.946 & 0.543 & 7.175 & -0.076 & -0.038 & 0.580 & 8.160 \\
\hline $\operatorname{EP}(1)^{*}$ & -1.078 & -0.014 & 0.522 & 5.698 & -16.122 & -1.665 & 0.216 & 6.739 & -15.137 & -0.680 & 0.254 & 7.724 \\
\hline$H C_{\mathbb{N}_{N}}(1)^{*}$ & -3.945 & -0.295 & 0.983 & 8.293 & -2.345 & -1.138 & 0.671 & 9.139 & -1.360 & -0.153 & 0.708 & 10.12 \\
\hline$\Delta \mathrm{EG}_{\mathrm{R}}(0)^{*}$ & -9.121 & -2.406 & 0.173 & 3.793 & -23.942 & -2.542 & 0.179 & 4.655 & -22.957 & -1.557 & 0.217 & 5.640 \\
\hline$\Delta E U_{A}(0)^{*}$ & -13.911 & -1.566 & 0.209 & 3.279 & -37.600 & -3.386 & 0.151 & 3.456 & -36.615 & -2.401 & 0.188 & 4.441 \\
\hline$\Delta \mathrm{EP}(0)^{*}$ & -13.689 & -1.713 & 0.221 & 2.692 & -19.023 & -2.177 & 0.195 & 5.539 & -18.038 & -1.192 & 0.233 & 6.524 \\
\hline$\Delta H C_{\mathbb{I N}}(0)^{*}$ & -10.156 & -0.999 & 0.153 & 1.862 & -27.775 & -6.334 & 0.083 & 2.449 & -26.790 & -5.349 & 0.121 & 3.434 \\
\hline Vg-Perron critical value 5\% & -7.115 & -0.995 & 0.270 & 4.155 & -16.315 & -1.925 & 0.205 & 6.465 & -15.330 & -0.940 & 0.243 & 7.450 \\
\hline
\end{tabular}

$M Z_{a}$ modified version of the Phillips (1987) $Z_{a}$ test, $M Z_{t}$ modified version of the Phillips-Perron (1988) $Z_{\mathrm{t}}$ test, $M S B$ the Perron and Ng (1996) spectral density test, Modified MPT modified feasible point optimal test, $E G_{R}$ renewable energy generation, $E U_{A}$ aggregated energy use, $E P$ economic performance, $H C_{I N}$ human capital index

$$
\begin{aligned}
\mathrm{EP}= & 0.818+2.134 \mathrm{EG}_{\mathrm{R}}+2.644 \mathrm{EU}_{\mathrm{A}} \\
& +2.306 \mathrm{HC}_{\mathrm{IN}}
\end{aligned}
$$

$(p$ value $=0.030) \quad(p$ value $=0.050)(p$ value $=0.001)$

The normalized specification according to $\mathrm{EG}_{\mathrm{R}}$ :

$$
\begin{aligned}
\mathrm{EG}_{\mathrm{R}}= & -1.441+1.993 \mathrm{EP}+2.440 \mathrm{EU}_{\mathrm{A}} \\
& +1.374 \mathrm{HC}_{\mathrm{IN}} \\
(p \text { value }= & 0.025) \quad(p \text { value }=0.245)(p \text { value }=0.013)
\end{aligned}
$$

The normalized specification according to $\mathrm{EU}_{\mathrm{A}}$ :

$$
\begin{aligned}
\mathrm{EU}_{\mathrm{A}}= & 0.645+2.102 \mathrm{EP}+2.516 \mathrm{EG}_{\mathrm{R}} \\
& +1.130 \mathrm{HC}_{\mathrm{IN}} \\
(p \text { value }= & 0.010) \quad(p \text { value }=0.000)(p \text { value }=0.050)
\end{aligned}
$$

The normalized specification according to $\mathrm{HC}_{\mathrm{IN}}$ :

$$
\begin{aligned}
\mathrm{HC}_{\mathrm{IN}}= & 0.391+1.918 \mathrm{EP}+1.259 \mathrm{EG}_{\mathrm{R}} \\
& +1.556 \mathrm{EU}_{\mathrm{A}} \\
(p \text { value }= & 0.055) \quad(p \text { value }=0.193)(p \text { value }=0.315)
\end{aligned}
$$

Specification 1 explains the positive influence of renewable energy generation, aggregated energy use, and human capital on economic performance in the long term. It implies that progress in the economic performance is caused by an enhanced aggregated energy use [53] as well as a renewable energy generation in the long term. Likewise, the accumulation of human capital implies that the addition of skilled labor equipped with knowledge makes a technological adoption quicker and thus improves the performance of an economy [6]. Specification 2 demonstrates the positive influence of economic performance and human capital on renewable energy generation in the long run. At the same time, a neutral influence of the aggregated energy use on renewable energy generation was also observed in the same specification. It implies that human capital improves economic performance which promotes the generation of renewable energy. Next, specification 3 demonstrates a significant influence of economic performance, renewable energy generation, and human capital on aggregated energy use in the long term. Finally, specification 4 demonstrates that the economic performance imparted a positive and significant impact on human capital. However, human capital remained neutral to changes in renewable energy generation, and aggregated energy use. When the given specifications in the normalized form are observed together, a positive bilateral association between economic performance and renewable energy generation, aggregated energy use and economic performance [54], and human capital and economic growth $[55,56]$ can be seen in the long term. However,

Table 4 Results of the VAR lag length analysis

\begin{tabular}{llllll}
\hline Lag & $\begin{array}{l}\text { Final prediction error } \\
\text { (FPE) }\end{array}$ & $\begin{array}{l}\text { Akaike information } \\
\text { criterion (AIC) }\end{array}$ & $\begin{array}{l}\text { Schwarz information } \\
\text { criterion (SC) }\end{array}$ & $\begin{array}{l}\text { Hannan-Quinn information } \\
\text { criterion (HQ) }\end{array}$ & $\begin{array}{l}\text { Deviance information } \\
\text { criterion (DIC) }\end{array}$ \\
\hline 0 & $10.2 \times 10^{19}$ & 60.147 & 60.282 & 60.193 & 53.934 \\
1 & $1.7 \times 10^{18^{*}}$ & 49.638 & $50.176^{*}$ & 49.821 & $57.828^{*}$ \\
2 & $4.0 \times 10^{18}$ & 49.957 & 50.899 & $50.278^{*}$ & 48.796 \\
3 & $3.4 \times 10^{18}$ & 49.967 & 51.314 & 50.427 & 51.472 \\
4 & $5.1 \times 10^{13}$ & 51.143 & 53.796 & 48.683 & 50.314 \\
\hline
\end{tabular}

*Denotes the lag order selected by the criterion at a $5 \%$ level 
Table $\mathbf{5}$ Result of the Johansen and Juselius analysis

\begin{tabular}{|c|c|c|c|c|}
\hline $\begin{array}{l}\text { Hypothesized } \\
\text { No of CE (s) }\end{array}$ & Eigen-values & Trace statistics & 0.05 critical value & Prob. \\
\hline None $^{*}$ & 0.723 & 55.325 & 32.915 & 0.000 \\
\hline At most 1 & 0.441 & 23.576 & 35.872 & 0.350 \\
\hline At most 2 & 0.291 & 9.146 & 7.017 & 0.725 \\
\hline At most 3 & 0.369 & 19.964 & 26.233 & 0.375 \\
\hline \multicolumn{5}{|c|}{ Trace test indicates 1 co-integrating specification at a 0.05 level } \\
\hline $\begin{array}{l}\text { Hypothesized } \\
\text { No of CE (s) }\end{array}$ & Eigen-values & Max-Eigen statistics & 0.05 critical value & Prob. \\
\hline None $^{*}$ & 0.723 & 33.069 & 15.823 & 0.000 \\
\hline At most 1 & 0.441 & 16.068 & 29.387 & 0.233 \\
\hline At most 2 & 0.291 & 10.147 & 18.017 & 0.637 \\
\hline At most 3 & 0.369 & 12.941 & 21.287 & 0.160 \\
\hline
\end{tabular}

Null hypothesis no co-integration, Eigen eigenvalue, Max-Eigen maximum eigenvalue, CE co-integrating equation. ${ }^{*}$ denotes rejection of the hypothesis at the Prob. $\leq .05$ level

the specifications in the normalized form demonstrate a unilateral positive causal association running from renewable energy generation to aggregated energy use, human capital to aggregated energy use, and human capital to renewable energy generation during the time span under investigation.

\section{Vector error correction model-based empirical results}

The long-term associations among the given variables help formulate a VECM which explicitly incorporates the component of an error correction term acquired from co-integration regressions and in this context, the objective is to find the source of causal links.

The VECM specifications established in the current research are as follows:

$$
\begin{aligned}
\Delta(\mathrm{EP}) t= & \alpha 1+\beta 1\left(\mathrm{EU}_{\mathrm{A}}\right) t-1+\Upsilon 1 \Delta(\mathrm{EP}) t-1 \\
& +\Psi 1 \Delta\left(\mathrm{EG}_{\mathrm{R}}\right) t-1 \\
& +\quad \phi 1 \Delta\left(\mathrm{EU}_{\mathrm{A}}\right) t-1 \\
& +\lambda 1 \Delta\left(\mathrm{HC}_{\mathrm{IN}}\right) t-1+u 1
\end{aligned}
$$

Table 6 Co-integrating models

\begin{tabular}{lllllll}
\hline Specification 1 & $\mathrm{EP}$ & $\mathrm{EP}$ & $\mathrm{EG}$ & $\mathrm{EU}_{\mathrm{A}}$ & $\mathrm{HC}_{\mathbb{I N}_{\mathrm{N}}}$ & $\mathrm{C}$ \\
& & +2.312 & +4.935 & +6.115 & +5.332 & +1.892 \\
\hline Specification 2 & $\mathrm{EG}_{\mathrm{R}}$ & $\mathrm{EG}_{\mathrm{R}}$ & $\mathrm{EP}$ & $\mathrm{EU}_{\mathrm{A}}$ & $\mathrm{HC}_{\mathbb{I N}}$ & $\mathrm{C}$ \\
& & +3.005 & +5.991 & -7.334 & -4.129 & -4.331 \\
Specification 3 & $\mathrm{EU}_{\mathrm{A}}$ & $\mathrm{EU}_{\mathrm{A}}$ & $\mathrm{EP}$ & $\mathrm{EG}_{\mathrm{R}}$ & $\mathrm{HC}_{\mathbb{I N}}$ & $\mathrm{C}$ \\
& & +2.915 & +6.129 & -7.335 & -3.295 & +1.882 \\
Specification 4 & $\mathrm{HC}_{\mathbb{I N}_{\mathrm{N}}}$ & $\mathrm{HC}$ & $\mathrm{EP}$ & $\mathrm{EG}_{\mathrm{R}}$ & $\mathrm{EU}_{\mathrm{A}}$ & $\mathrm{C}$ \\
& & +3.299 & +6.330 & +4.156 & +5.135 & +1.290 \\
\hline
\end{tabular}

$C$ constant, $E G_{R}$ renewable energy generation, $E U_{A}$ aggregated energy use, $E P$ economic performance, $H C_{I N}$ human capital index

$$
\begin{aligned}
\Delta\left(\mathrm{EP}_{\mathrm{R}}\right) t= & \alpha 2+\beta 2\left(\mathrm{EU}_{\mathrm{A}}\right) t-1+\Upsilon 2 \Delta(\mathrm{EP}) t-1 \\
& +\Psi 2 \Delta\left(\mathrm{EG}_{\mathrm{R}}\right) t-1+\phi 2 \Delta\left(\mathrm{EU}_{\mathrm{A}}\right) t-1 \\
& +\lambda 2 \Delta\left(\mathrm{HC}_{\mathrm{IN}}\right) t-1+u 2 \\
\Delta\left(\mathrm{EU}_{\mathrm{A}}\right)= & \alpha 3+\beta 3\left(\mathrm{EU}_{\mathrm{A}}\right) t-1+\Upsilon 3 \Delta(\mathrm{EP}) t-1 \\
& +\Psi 3 \Delta\left(\mathrm{EG}_{\mathrm{R}}\right) t-1+\phi 3 \Delta\left(\mathrm{EU}_{\mathrm{A}}\right) t-1 \\
& +\lambda 3 \Delta\left(\mathrm{HC}_{\mathrm{IN}}\right) t-1+u 3 \\
\Delta\left(\mathrm{HC}_{\mathrm{IN}}\right) t= & \alpha 4+\beta 4\left(\mathrm{EU}_{\mathrm{A}}\right) t-1+\Upsilon 4 \Delta(\mathrm{EP}) t-1 \\
& +\Psi 4 \Delta\left(\mathrm{EG}_{\mathrm{R}}\right) t-1+\phi \Delta\left(\mathrm{EU_{ \textrm {A } }}\right) t-1 \\
& +\lambda 4 \Delta\left(\mathrm{HC}_{\mathrm{IN}}\right) t-1+u 4
\end{aligned}
$$

The findings of the VECM are listed in Table 8.

The ECM (-1) term, which encodes the long-run error-correction term allied with co-integration, interprets the size of the prior imbalance. Empirically, a negative error correction coefficient is predicted and proved to be statistically significant at a $5 \%$ level of significance for specifications $5,6,7$, and 8 , respectively. Specification 4 reveals that a long-run causal linkage is operating from renewable energy generation and aggregated energy use to economic performance.

This finding complies with the findings of the $\mathrm{JJ}$ cointegration analysis. Based on specifications $5-8$, a causal links exists among economic performance, aggregated energy use, renewable energy generation, and human capital. The value of $R^{2}$ for all the specifications are $0.925,0.895,525$, and 859 , which exposed that the arguments made for these specifications are overall a good fit. The causal links in specifications 5-8 confirmed the findings found in specifications $1-4$ given in the normalized form.

\section{Short-run causal links through granger causality}

For a further investigation of the causal links, the shortrun association among these variables was tested by 
Table 7 Normalized co-integrating models

\begin{tabular}{lllllll}
\hline Specification 1 & $E P$ & $E P$ & $E G_{R}$ & $E U_{A}$ & $H C_{\mathbb{N}}$ & $C$ \\
& & 1 & 2.134 & 2.644 & 2.306 & 0.818 \\
\hline Specification 2 & $E G_{R}$ & $E G_{R}$ & $E P$ & $E U_{A}$ & $H C_{\mathbb{N}}$ & $C$ \\
& & 1 & 1.993 & -2.440 & -1.374 & -1.441 \\
Specification 3 & $E U_{A}$ & $E U_{A}$ & $E P$ & $E G_{R}$ & $H C_{\mathbb{N}}$ & $C$ \\
& & 1 & 2.102 & -2.516 & -1.130 & 0.645 \\
Specification 4 & $H C_{\mathbb{I N}}$ & $H C_{\mathbb{N N}}$ & $E P$ & $E G_{R}$ & $E U_{A}$ & $C$ \\
& & 1 & 1.918 & 1.259 & 1.556 & 0.391
\end{tabular}

$C$ constant, $E G_{R}$ renewable energy generation, $E U_{A}$ aggregated energy use, $E P$ economic performance, $H C_{I N}$ human capital index

conducting the Granger Causal link analysis. The lag length was found to be 1 for the Granger causality test, according to the information criteria of FPE and HQ. The findings are presented in Table 9.

The above-mentioned results declare a bilateral causality association between economic performance and renewable energy generation and there is a one-way causal association from the aggregated energy use to the economic performance in the short term. It was observed that these results obtained for the short-term test are in correspondence with the results of the long-term test. These causal links with their parameter coefficients obtained from the long-run estimates and the directionality from the causality analysis are displayed in Fig. 4.

\section{Cholesky one standard deviation impulse response functions}

As a final step, the influence of an "arbitrary shock" in one variable caused by another variable in the system was determined via the impulse response functions. Putting it in another way, the impulse responses uncovered the influence of a shock, which had produced a standard error shock on one of the disturbance terms in the present and future values of the variables in the VAR system. These outputs of the impulse responses, according to Cholesky on the standard deviation, are depicted in Fig. 5.

The response of economic performance to aggregated energy use remained stable in the first half of the time period, and in the second half period, it increased gradually. During the first quarter of the time, the economic performance to human capital rose and in the remaining three quarters of time, it remained stable. For a response of economic performance to renewable energy generation, in the first half of time, economic performance improved slightly and remained stable; however, in the second half of the period, it reduced slightly and remained stable throughout the course of duration.

In the case of response of aggregated energy use to economic performance, the aggregated energy use is reported to positively affect the economic performance, which kept increasing along the time period. In the case of response of aggregated energy use to human capital, during the first half of the time period, aggregated energy use remained stable and afterward, it increased gradually. In the case of response of aggregated energy use to renewable energy generation, in response to a rise in renewable energy generation, the aggregated energy use started increasing after the first quarter of time and then kept on rising.

In the case of response of human capital to economic performance, the human capital is accelerated in response to a positive shock in economic performance throughout the time period. In the case of response of human capital to aggregated energy use, human capital slightly increased in the first half of time and in the second half, it became stable. As to a response of human capital to renewable energy generation, the human capital in response to a positive shock on renewable energy generation decreased slightly and then improved slightly throughout the whole time period.

In the case of response of renewable energy generation to economic performance, a positive economic performance

Table 8 The empirical findings based on the vector error correction model

\begin{tabular}{|c|c|c|c|c|}
\hline & $\begin{array}{l}\text { Specification } 5 \\
\Delta(E P)\end{array}$ & $\begin{array}{l}\text { Specification } 6 \\
\Delta\left(E_{R}\right)\end{array}$ & $\begin{array}{l}\text { Specification } 7 \\
\Delta\left(E \cup_{A}\right)\end{array}$ & $\begin{array}{l}\text { Specification } 8 \\
\Delta\left(H C_{\mathbb{N}_{N}}\right)\end{array}$ \\
\hline$\overline{\mathrm{ECM}}(-1)$ & $-0.954(0.025)$ & $-10,094.540(0.009)$ & $-309.325(0.050)$ & $-0.190(0.090)$ \\
\hline$\Delta(E P(-1))$ & $0.057(0.092)$ & $2040.003(0.085)$ & $-151.420(0.054)$ & $0.357(0.003)$ \\
\hline$\Delta\left(E_{R}(-1)\right)$ & $-2.2 \times 10^{3}(0.075)$ & $0.547(0.000)$ & $0.233(0.042)$ & $0.577(0.052)$ \\
\hline$\Delta\left(\mathrm{EU}_{\mathrm{A}}(-1)\right)$ & $0.009(0.095)$ & $7.294(0.010)$ & $-0.403(0.035)$ & $0.395(0.035)$ \\
\hline$\Delta\left(H C_{\mathbb{N}_{N}}(-1)\right)$ & $0.0127(0.006)$ & $4.837(0.008)$ & $0.829(0.015)$ & $0.019(0.013)$ \\
\hline$C$ & $3.470(0.049)$ & $-7806.684(0.090)$ & $4122.740(0.000)$ & $5.698(0.000)$ \\
\hline$R$-squared & 0.925 & 0.895 & 0.524 & 0.859 \\
\hline Adj. R-squared & 0.953 & 0.886 & 0.520 & 0.841 \\
\hline F-statistics & 43.316 & 78.035 & 38.974 & 41.192 \\
\hline
\end{tabular}

$C$ constant, $E G_{R}$ renewable energy generation, $E U_{A}$ aggregated energy use, $E P$ economic performance, $H C_{I N}$ human capital index, $R$-squared coefficient of determination, $A d j$. adjusted, $F$-statistics overall significance of the model 


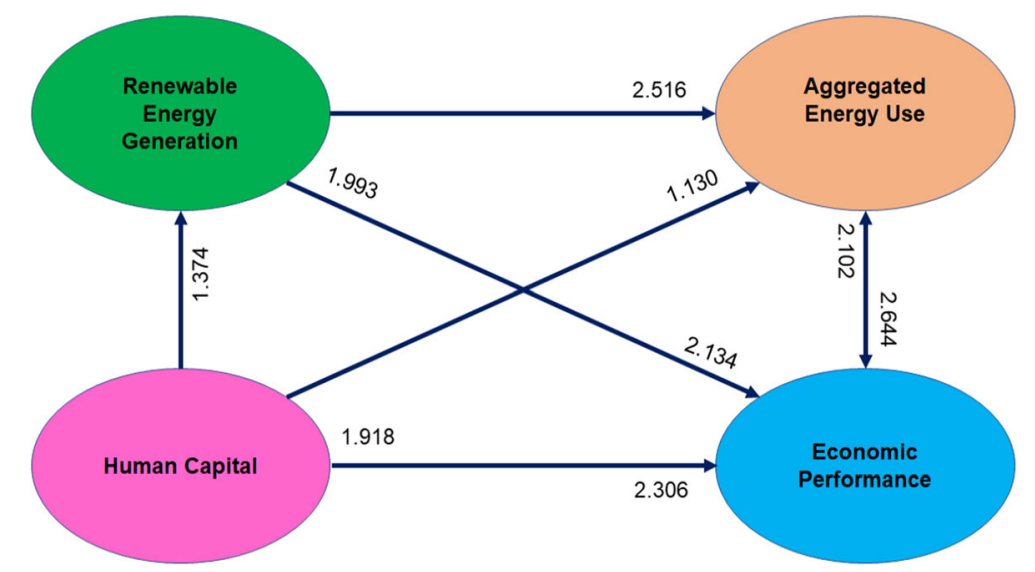

Fig. 4 Summary of causal links between renewable energy generation, aggregated energy use, human capital, and economic performance

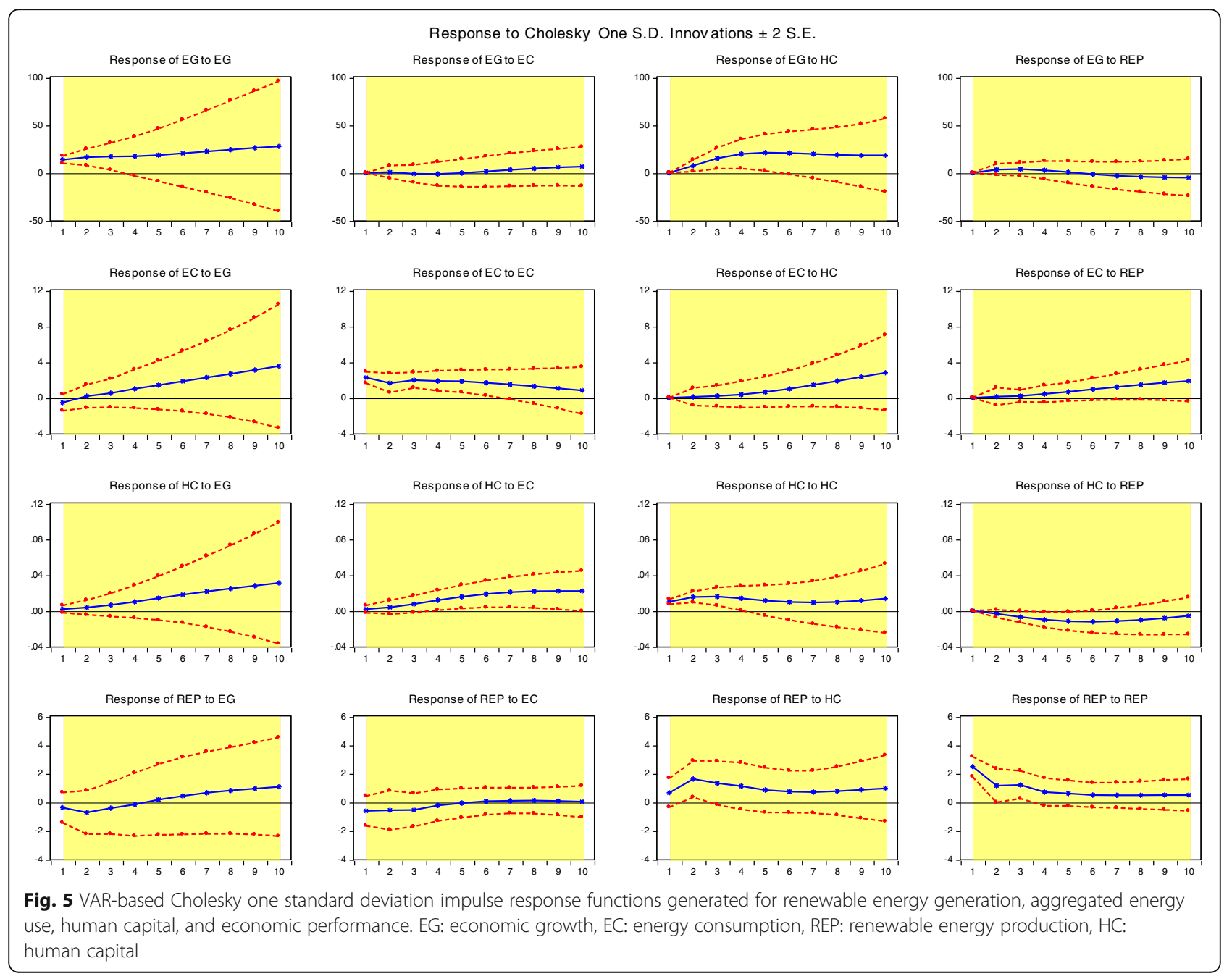


shock induced a positive response to renewable energy generation within the whole course of time. As to a response of renewable energy generation to aggregated energy use, during the first half of the time period, the positive shock on aggregated energy use brought a slight rise in renewable energy generation which became stable for the rest of the time. In response to a positive shock on human capital, renewable energy generation decreased slightly and afterward, it became stable.

\section{Conclusions and implications}

This is an empirical attempt to systematically examine the long-term, as well as short-term, interactions between renewable energy generation, aggregated energy use, human capital, and economic performance in Pakistan for time series data spanning from 1980 to 2016. Unlike previous studies, at first, a long-term test among the variables of interest was established which was the maiden empirical attempt in the literature. Secondly, the analysis of interactions between renewable energy generation, energy use, human capital, and economic performance in the context of Pakistan's economy is the first known attempt carried out in the current study. As a primary step, a time series unit root analysis was conducted making use of ADF, PP, KPSS, and ADFGLS tests. As the main methodology, JJ co-integration was used to determine the presence of a long-term association among the variables of interest. Finally, within the VAR modeling framework, the ECM was applied and the impulse response functions were estimated. The Granger causality and impulse-response tests were conducted with the aim to analyze the short-term causality relations. The findings of a former test interpreted the existence of long-term associations between renewable energy generation, aggregated energy use, human capital, and economic performance. The normalized specifications obtained from the co-integration analysis demonstrate the existence of a positive bi-lateral causal association between renewable energy generation and economic performance, aggregated energy use and economic performance, and human capital and economic performance in the long term as well as in the short term. Furthermore, a positive unilateral causal link was uncovered running from renewable energy generation and human capital to aggregated energy use. Likewise, a positive unilateral link running from human capital to renewable energy generation was evidenced.

The findings of the Granger causality analysis, in sequence with the results determined for the long-term test, also confirmed the existence of a bilateral causal association between the generation of renewable energy and economic performance, a one-way causal link running from aggregated energy use to economic performance in the short term. In continuation, when Granger causality and impulse response functions findings were investigated together, a positive bilateral causality relation of economic performance with renewable energy generation, aggregated energy use, and human capital was declared in the short-term test. Additionally, according to Granger causality findings between aggregated energy use and renewable energy generation and human capital, a one-way causal link from two of them to aggregated energy use was observed.

The interrelated links among renewable energy generation, aggregated energy use, human capital, and economic performance demonstrated the significance of renewable energy in enhancing economic performance and vice versa. In addition, the government should pay attention to the above-stated interrelated links when formulating strategies for renewable energy generation and overall usage of aggregated energy. Furthermore, the generation of renewable energy should be promoted, which could foster the energy sector development as an impetus to ultimately attain the sustainability goals, defined by government bodies. Moreover, to smooth the growth of the renewable energy sector, economic performance is essential in generating the requisite resources to support the research and development of renewable energy technologies and establishing the essential setup.

\section{Abbreviations \\ $\rightarrow$ : Unilateral causality; $\leftrightarrow$ : Bilateral causality; ADF: Augmented Dickey-Fuller; ADF-GLS: Augmented Dickey-Fuller-generalized least squares; AIC: Akaike information criterion; ARDL: Autoregressive distribution lag; BRIC \\ countries: Brazil, Russia, India China; C: Constant; CE: Co-integrating equation; $\mathrm{CO}_{2}$ : Carbon dioxide; EC: Energy consumption; EG: Economic growth; \\ $E_{R}$ : Renewable energy generation; EP: Economic performance; EU: European; $\mathrm{EU}_{\mathrm{A}}$ : Aggregated energy use; Fd.: Fixed; GDP: Gross domestic product; GLS: Generalized least square; HC: Human capital; $\mathrm{HC}_{\mathbb{I N}}$ : Human capital index; HQC: Hannan-Quinn information criterion; HR: Human resource; JJ: Johansen Juselius co-integration test; KPSS: Kwiatkowski-Phillips-Schmidt- Shin; KSA: Kingdom of Saudi Arabia; LM: Lagrange multiplier; MPT: Modified feasible point optimal test; MSB: Perron and Ng (1996) spectral density test modified; $M Z_{\mathrm{t}}$ : Modified version of Phillips-Perron (1988) $Z_{\mathrm{t}}$ test; \\ $M Z_{\alpha}$ : Modified version of Phillips (1987) $Z_{\alpha}$ test; OECD: Organization for economic co-operation and development; $P$ : Probability value; PP: Phillips- Perron; REP: Renewable energy production; SBC: Schwarz Bayesian criterion; Tr.: Trend; UK: United Kingdom; US: United States; VAR: Vector autoregressive; VECM: Vector error correction model; $\Delta$ : A first-order difference of variables; T: ADF-GLS test values}

\section{Acknowledgements}

The authors pay great regards to Beijing Social Science Foundation Research based Project and North China Electric Power University, Beijing, China.

\section{Authors' contributions}

NF conceived the idea, conducted the study, and drafted the manuscript. YL guided the whole process. MA helped in analysis and modeling. GJ reviewed and furnished the manuscript. XL made the final corrections in the manuscript. All authors read and approved the final manuscript.

\section{Funding}

This research is funded by the Beijing Social Science Foundation Research based Project (Grant no. 17JDGLA009). 


\section{Availability of data and materials}

The data and materials used are given in this paper in the form of tables and figures.

\section{Ethics approval and consent to participate}

It is declared that the paper does not involve violation of any human rights, illegal use of data, or copyright protected materials.

\section{Consent for publication}

This paper does not involve any ones data (i.e., individual data, table, figures etc.).

\section{Competing interests}

The authors declare that they have no competing interests.

Received: 14 May 2019 Accepted: 14 November 2019

Published online: 11 December 2019

\section{References}

1. Riti JS, Shu Y (2016) Renewable energy, energy efficiency, and eco-friendly environment (R-E5) in Nigeria. Energy. Sustain. Soc 6(1):1-16

2. Ohler A, Fetters I (2014) The causal relationship between renewable electricity generation and GDP growth : a study of energy sources it Energy Econ 43:125-139

3. Ahmad M, Zhao ZY (2018) Empirics on linkages among industrialization, urbanization, energy consumption, CO2 emissions and economic growth: a heterogeneous panel study of China. Environ. Sci. Pollut. Res 25(30):3061730632

4. G. Tuna and V. E. Tuna, "The asymmetric causal relationship between renewable and NON-RENEWABLE energy consumption and economic growth in the ASEAN-5 countries," Resour. Policy, vol. 62, no. November 2018, pp. 114-124, 2019.

5. R. N. Dar-mousa, "Analysis of the pattern of energy consumptions and its impact on urban environmental sustainability in Jordan : Amman City as a case study," vol. 0, 2019.

6. M. Ahmad and R. E. A. Khan, "Does demographic transition with human capital dynamics matter for economic growth? A dynamic panel data approach to GMM," Soc. Indic. Res., no. May, pp. 1-20, 2018.

7. A. R. Ã. Karbassi, M. A. Abduli, and E. M. Abdollahzadeh, "Sustainability of energy production and use in Iran," vol. 35, pp. 5171-5180, 2007.

8. Fang Z, Chang Y (2016) Energy, human capital and economic growth in Asia Pacific countries - evidence from a panel cointegration and causality analysis. Energy Econ 56:177-184

9. W. Liu, "Is renewable energy effective in promoting local economic development? The case of China," J. Renew. Sustain. Energy, vol. 8, no. 2, 2016.

10. Mankiw NG (1990) A contribution to the empirics of economic growth abstract

11. J. Benhabib and M. M. Spiegel, "Chapter 13 Human capital and technology diffusion," Handb. Econ. Growth, vol. 1, no. SUPPL. PART A, pp. 935-966, 2005.

12. Grunwald A, Rösch C (2011) Sustainability assessment of energy technologies: towards an integrative framework. Energy. Sustain. Soc. 1(1):1-10

13. J. Ruotsalainen, J. Karjalainen, M. Child, and S. Heinonen, "Culture, values, lifestyles, and power in energy futures: a critical peer-to-peer vision for renewable energy," Energy Res. Soc. Sci., vol. 34, no. July, pp. 231-239, 2017.

14. K. Alizada, "Rethinking the diffusion of renewable energy policies: a global assessment of feed-in tariffs and renewable portfolio standards," Energy Res. Soc. Sci., vol. 44, no. May 2017, pp. 346-361, 2018.

15. M. Stoppok, A. Jess, R. Freitag, and E. Alber, "Of culture, consumption and cost: a comparative analysis of household energy consumption in Kenya, Germany and Spain," Energy Res. Soc. Sci., vol. 40, no. December 2017, pp. 127-139, 2018.

16. P. Greenberg and D. Bugden, "Energy consumption boomtowns in the United States: community responses to a cryptocurrency boom," Energy Res. Soc. Sci., vol. 50, no. August 2018, pp. 162-167, 2019.

17. O. Bayulgen and S. Benegal, "Green priorities: how economic frames affect perceptions of renewable energy in the United States," Energy Res. Soc. Sci., vol. 47, no. August 2018, pp. 28-36, 2019.

18. Mathiesen BV, Lund H, Karlsson K (2011) 100\% renewable energy systems, climate mitigation and economic growth. Appl. Energy 88(2):488-501
19. Menyah K, Wolde-Rufael Y (2010) CO2 emissions, nuclear energy, renewable energy and economic growth in the US. Energy Policy 38(6):2911-2915

20. S. O. Oyedepo, "Energy and sustainable development in Nigeria: the way forward Sustainable energy Renewable energy Energy efficiency Energy conservation Review Background," pp. 1-17, 2012.

21. Ahmad S, Tahar RM (2014) Selection of renewable energy sources for sustainable development of electricity generation system using analytic hierarchy process : a case of Malaysia. Renew. Energy 63:458-466

22. Lund H (2007) Renewable energy strategies for sustainable development. ScienceDirect 32:912-919

23. M. del P. Pablo-Romero and A. Sánchez-Braza, "Productive energy use and economic growth: energy, physical and human capital relationships," Energy Econ., vol. 49, pp. 420-429, 2015.

24. A. Rehman, Z. Deyuan, A. A. Chandio, and I. Hussain, "An empirical analysis of rural and urban populations' access to electricity: evidence from Pakistan," Energy. Sustain. Soc., vol. 8, no. 1, 2018.

25. Ayres RU (2008) Energy and economic growth robert $u$. ayres * Production:1-23

26. Lean HH, Smyth R (2014) Disaggregated energy demand by fuel type and economic growth in Malaysia. Appl. Energy 132:168-177

27. Ahmad M, Zhao ZY (2018) Causal linkages between energy investment and economic growth: a panel data modelling analysis of China. Energy Sources, Part B Econ. Plan. Policy 13(8):363-374

28. Apergis N, Payne JE (2010) Renewable energy consumption and economic growth: evidence from a panel of OECD countries. Energy Policy 38(3): 1353-1359

29. A. Rehman and Z. Deyuan, "Pakistan's energy scenario: a forecast of commercial energy consumption and supply from different sources through 2030," Energy. Sustain. Soc., vol. 8, no. 1, pp. 0-4, 2018.

30. Fang Z, Wolski M (2016) Human capital, energy and economic growth in China - evidence from multivariate nonlinear Granger causality. Eur. Invest. Bank 1(1):1-25

31. T. Stela Z, "Energy consumption and economic growth: a causality analysis for Greece," Energy Econ., vol. 32, no. 3, pp. 582-590, 2010.

32. Altunbas Y, Kapusuzoglu A (2015) The causality between energy consumption and economic growth in United Kingdom. Econ. Res. Istraživanja 24(2):60-67

33. Alshehry AS, Belloumi M (2015) Energy consumption, carbon dioxide emissions and economic growth: the case of Saudi Arabia. Renew. Sustain. Energy Rev 41:237-247

34. Ocal O, Aslan A (2013) Renewable energy consumption-economic growth nexus in Turkey. Renew. Sustain. Energy Rev 28:494-499

35. Sebri M, Ben-Salha O (2014) On the causal dynamics between economic growth, renewable energy consumption, CO2emissions and trade openness: fresh evidence from BRICS countries. Renew. Sustain. Energy Rev 39:14-23

36. J. Čadil, L. Petkovová, and D. Blatná, "Human capital, economic structure and growth," Procedia Econ. Financ., vol. 12, no. March, pp. 85-92, 2014.

37. Kottaridi C, Stengos T (2010) Foreign direct investment, human capital and non-linearities in economic growth. J. Macroecon. 32(3):858-871

38. Tugcu CT, Ozturk I, Aslan A (2012) Renewable and non-renewable energy consumption and economic growth relationship revisited: evidence from G7 countries. Energy Econ 34(6):1942-1950

39. Apergis N, Payne JE (2010) Renewable energy consumption and growth in Eurasia. Energy Econ 32(6):1392-1397

40. F. Alaali, J. Roberts, K. Taylor, F. Alaali, J. Roberts, and K. Taylor, "The effect of energy consumption and human capital on economic growth : an exploration of oil exporting and developed countries," no. 2015015, 2015.

41. A. Rehman, I. Ozturk, and D. Zhang, "The causal connection between CO2 emissions and agricultural productivity in Pakistan: empirical evidence from an autoregressive distributed lag bounds testing approach," Appl. Sci., vol. 9, no. 8, p. 1692, 2019

42. S. Maamar and B. O. Salha, "On the causal dynamics between economic growth, renewable energy consumption, $\mathrm{CO} 2$ emissions and trade openness: fresh evidence from BRICS countries," Renew. Sustain. Energy Rev. no. 39, pp. 14-23, 2013.

43. Curea ŞC, Ciora C (2013) The impact of human capital on economic growth. Qual Access to Success 14(SUPPL. 1):395-399

44. Ali HS, Law SH, Yusop Z, Chin L (2017) Dynamic implication of biomass energy consumption on economic growth in Sub-Saharan Africa: evidence from panel data analysis. GeoJournal 82(3):493-502 
45. X. Xu and C. K. Liu, "How to keep renewable energy enterprises to reach economic sustainable performance: from the views of intellectual capital and life cycle," Energy. Sustain. Soc., vol. 9, no. 1, 2019.

46. World Development Indicators (2019) World Bank database. Available online: https://data. worldbank.org/indicator/ny.gdp.mktp.kd.zg

47. Penn World Tables-9.0 (2019). Available online: https://fred.stlouisfed.org/ release? rid $=285$

48. Dickey DA, Fuller WA (1981) Likelihood ratio statistics for autoregressive time series with a unit root. Journal of the Econometric Society, Econometrica, pp 1057-1072

49. C. B. P. Phillips and P. Perron, "Testing for a unit root in time series regresson." Biometrica, pp. 335-46, 1988.

50. Kwatkowski D, Phillips PCB, Schmidt P, Shin Y (1992) Testing the null hypothesis of stationarity against the alternative of a unit root. J. Econom. 54:159-178

51. S. Ng and P. Pierre, "LAG length selection and the construction of unit root tests with good size and power JEL classication : C2 , C3, C5 1 introduction," no. February, 1998

52. Johansen S, Juselius K (1990) Maximum likelihood estimation and inference on cointegration - with applications to the demand for money. Oxford Bull Econ Stat 52(2):169-210

53. Yildirim E, Saraç \$, Aslan A (2012) Energy consumption and economic growth in the USA: evidence from renewable energy. Renew Sustain Energy Rev 16(9):6770-6774

54. Rehman A, Rauf A, Ahmad M, Chandio AA, Deyuan Z (2019) The effect of carbon dioxide emission and the consumption of electrical energy, fossil fuel energy, and renewable energy, on economic performance: evidence from Pakistan. Environmental Science and Pollution Research. https://doi. org/10.1007/s11356-019-05550-y

55. Fleisher B, Li H, Zhao MQ (2010) Human capital, economic growth, and regional inequality in China. J. Dev. Econ. 92(2):215-231

56. Storper M, Scott AJ (2009) Rethinking human capital, creativity and urban growth. J. Econ. Geogr. 9(2):147-167

\section{Publisher's Note}

Springer Nature remains neutral with regard to jurisdictional claims in published maps and institutional affiliations.

Ready to submit your research? Choose BMC and benefit from:

- fast, convenient online submission

- thorough peer review by experienced researchers in your field

- rapid publication on acceptance

- support for research data, including large and complex data types

- gold Open Access which fosters wider collaboration and increased citations

- maximum visibility for your research: over $100 \mathrm{M}$ website views per year

At $\mathrm{BMC}$, research is always in progress.

Learn more biomedcentral.com/submissions 